\title{
Enhancing transgenic pea (Pisum sativum L.) resistance against fungal diseases through stacking of two antifungal genes (Chitinase and Glucanase)
}

\section{Awah Anna Amian, Jutta Papenbrock, Hans-Jörg Jacobsen \& Fathi Hassan}

To cite this article: Awah Anna Amian, Jutta Papenbrock, Hans-Jörg Jacobsen \& Fathi Hassan (2011) Enhancing transgenic pea (Pisum sativum L.) resistance against fungal diseases through stacking of two antifungal genes (Chitinase and Glucanase), GM Crops, 2:2, 104-109

To link to this article: http://dx.doi.org/10.4161/gmcr.2.2.16125

\section{(.) Copyright ( 2011 Landes Bioscience}

\section{曲 Published online: 01 Apr 2011.}

\section{Submit your article to this journal $₫$}

III Article views: 413

Q View related articles ¿

7 Citing articles: 18 View citing articles $ひ$ 


\title{
Enhancing transgenic pea (Pisum sativum L.) resistance against fungal diseases through stacking of two antifungal genes (chitinase and glucanase)
}

\author{
Awah Anna Amian, ${ }^{1}$ Jutta Papenbrock, ${ }^{2}$ Hans-Jörg Jacobsen' and Fathi Hassann ${ }^{1, *}$ \\ 'Gottfried Wilheim Leibniz Universität Hannover; Institute of Plant Biotechnology; ${ }^{2}$ Institute of Botany; Hannover, Germany
}

Key words: pea, combined transgenes, crossing, fungal resistance, expression stability

Abbreviations: bar, bialaphos resistance gene; PPT, phosphinothricin; PR-protein, pathogenesis related protein

\begin{abstract}
One way of enhancing and broadening resistance of plants to different biotic and abiotic stresses is to combine transgenes expressing several genes into a single line. This can be done using different strategies such as crossing, single vector with multiple genes, co-transformation, sequential transformation and IRES elements. In the present study, conventional crossing method was used. Parental transgenic lines transformed via Agrobacterium tumefasciens-mediated gene transformation with $p$ Greenll binary vector harboring a bar gene as a selectable marker in combination with the family 19 chitinase gene from Streptomyces olivaceoviridis for one line and 1,3- $\beta$-glucanase from barley (Hordeum vulgare) for the other line were used for crossing. Both chitinase and glucanase genes were cloned into $p G r e e n l l$ vector under the control of the constitutive double 35S-promoter from cauliflower mosaic virus. Progenies expressing the two genes were characterized at the molecular level using PCR, RT-PCR and Southern blot analysis, as well as segregation and stability studies of the respective expression levels. Leaf paint assay was used as a functional test for herbicide resistance genes. Stable inheritance of the antifungal genes in the transgenic plants was demonstrated. The synergistic effect of crossed plants was tested using in vitro assay which shows higher inhibition of spore germination.
\end{abstract}

\section{Introduction}

Diseases are considered the most important cause of high yield losses with fungal diseases being the most important, yield losses can range between $50-75 \% \cdot{ }^{1-4}$ Constitutive expression of individual PRs in transgenic plants can lead to reduced pathogen growth and symptom development, consistent with a role of PRs in the expression of acquired resistance. ${ }^{5,6}$ Dana et al. ${ }^{7}$ generated transgenic tobacco (Nicotiana tabacum) lines that overexpress the endochitinases CHIT33 and CHIT42 from the mycoparasitic fungus Trichoderma harzianum and evaluated their tolerance to biotic and abiotic stresses. Both CHIT33 and CHIT42, individually, conferred broad resistance against fungal and bacterial pathogens as well as tolerance to salinity and heavy metals. Transgenic plants overexpressing chitinases of several origins have been shown to exhibit enhanced levels of resistance to fungal infection and delayed disease symptoms when challenged with fungal pathogens. ${ }^{8-10}$

Most frequently described antifungal proteins are probably chitinases and $\beta-1,3$-glucanases. The expression of glucanase and chitinase genes respectively in plants enhances their resistance against fungal pathogens. ${ }^{11-13}$ It has also been demonstrated that these hydrolases act synergistically in both in vitro and in vivo assays, resulting in a very strong antifungal activity. ${ }^{14-16} \mathrm{~A}$ high level expression of these genes has been detected in transgenic rice and barley leading to a high resistance. ${ }^{8,17}$ The co-expression of chitinase and glucanase genes in tobacco enhanced resistance against Cercospora nicotianae. ${ }^{8,17-19}$ In tomato, simultaneous expression of the basic tobacco chitinase PR-3d and glucanase PR-2e provided substantial protection against Fusarium oxysporum f.sp. lycopersici, whereas transgenic plants expressing either one of these genes were not protected. ${ }^{20}$

Two or more transgenes can be sequentially introduced into a plant by conventional iterative procedures, e.g., a plant containing one transgene is crossed with individuals harboring other transgenes ${ }^{21}$ or alternatively, is re-transformed with new genes, ${ }^{22}$ co-transformation ${ }^{23}$ and dicistronic vector with IRES elements. ${ }^{24}$ The crossing techniques have been used at the research level to combine or reinforce existing transgenic traits. It has been demonstrated that crossing plants expressing different Bacillus thuringiensis $(\mathrm{Bt})$ toxins provided an effective way of delaying the emergence of Bt-resistant pests. Cao et al..$^{25}$ illustrated this in 


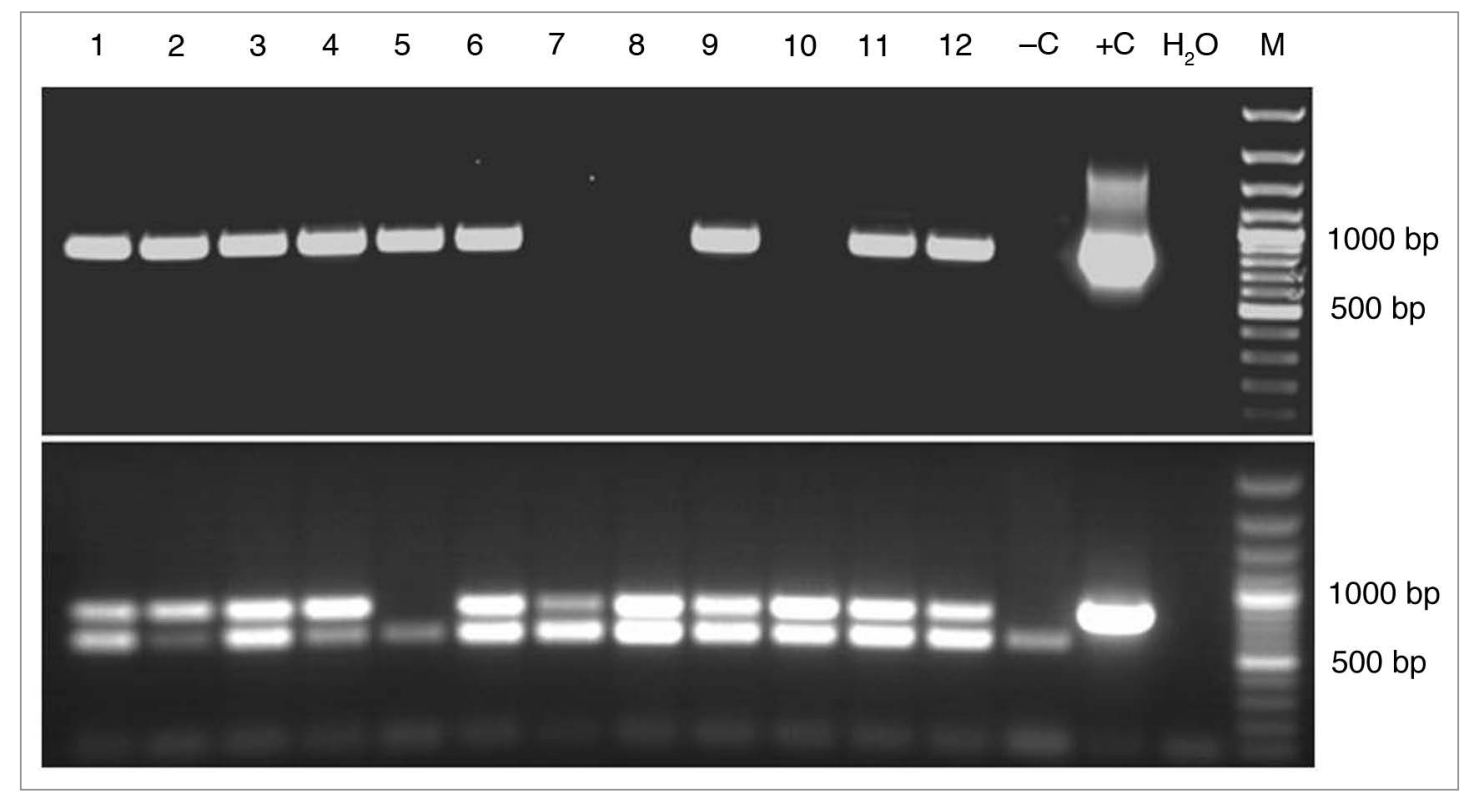

Figure 1. Simple and Multiplex PCR using primers for glucanase with product size of $750 \mathrm{bp}$ (upper photo), chitinase with amplification of 750 bp and HMG presenting product size $570 \mathrm{bp}$ (lower photo) to show segregation in the $F_{2}$ plants. Lanes $1-4,6,9,11$ and 12 have both genes while segregation is observed in lanes 5, 7, 8 and 10; -C, negative control untransformed plant; +C, positive control (Plasmid pGII-gluc and pGII-chit30) and M, 100 bp DNA molecular marker.

broccoli where pyramided $c r y 1 \mathrm{Ac}$ and $c r y 1 \mathrm{C}$ Bt genes controlled diamondback moths resistant to either single protein and significantly delayed the evolution of resistant insects. ${ }^{26}$ Similarly, Datta et al. ${ }^{27}$ developed disease- and pest-resistant rice by crossing plants expressing the $\mathrm{Xa21}$ gene (resistance to bacterial blight) with plants expressing both a $\mathrm{Bt}$ fusion gene and a chitinase gene (resistance to yellow stem borer and tolerance to sheath blight, respectively).

The objective of the present study was to enhance the resistance level of pea to fungal diseases by crossing two transgenic pea lines one expressing chitinase gene and the second expressing glucanase gene. The consequence was transgenic pea plants expressing both chitinase and glucanase genes.

\section{Results and Discussion}

One of the major problems impeding the advance of plant genetic engineering and biotechnology is the fact that the expression or manipulation of multiple genes in plants is still difficult to achieve. Gene pyramiding is emphasized to obtain many complex biochemical pathways in plants for crop improvement and durable resistance. Approaches can involve conventional sexual crossing, re-transformation, co-transformation and the use of linked transgenes. ${ }^{27}$ The level of expression of a transgene is variable and is influenced by various factors, such as the site of integration or position effect. ${ }^{28}$ Crossing of transgenic parental lines allows a direct evaluation of protective interaction between the transgenes in the crossed plants with that provided by each transgene alone at the same respective loci in the parental lines. ${ }^{29}$ Gene 'pyramiding' or 'stacking' present advantages and offer the potential for providing higher resistance to diseases. Interesting genes in this study were chitinase and $\beta$-1,3-glucanase, two of pathogenesis-related proteins, produced in response to microbial infection. These enzymes hydrolyse chitin and glucan, respectively of fungal cell walls. ${ }^{30}$

Successful introduction of the chitinase and glucanase genes into the pea genomic DNA was analysed using specific primers for the chitinase and glucanase in the $\mathrm{F}_{0}$ and subsequent generations (Fig. 1).

Copy numbers and integration patterns were investigated in the crossed transgenic $\mathrm{F}_{1}$ to $\mathrm{F}_{4}$ generations respectively using Southern blot analysis with different probes (chit and gluc). One or two copies were detected in the progenies which reflected the same copy numbers of the parental transgenic lines (Fig. 2).

RNA denaturing gel using formaldehyde was used to check the RNA integrity. Transcription of the glucanase and chitinase genes was confirmed using RT-PCR. Most of the crossed transgenic $\mathrm{F}_{1}$ to $\mathrm{F}_{4}$ generations clearly exhibited the transcription of the genes as shown in Figure 3.

Leaf paint assay was done to verify the expression of the bar gene. One week after application, clear effects of herbicide were observed (Fig. 4). The $600 \mathrm{mg} / \mathrm{l}$ of BASTA ${ }^{\circledR}$ used in the present study is high in comparison to that used by other groups, for example $200 \mathrm{mg} / \mathrm{l}$ on pea ${ }^{31}$ or $400 \mathrm{mg} / \mathrm{l}$ on faba bean (Vicia $f a b a) .{ }^{32}$ Recovery of herbicide resistant plants from sensitive parental plants through recombination in meiosis was observed in some lines. Table 1 shows a summary table of leaf paint results from $\mathrm{F}_{1}$ to $\mathrm{F}_{4}$ generations.

During the establishment of homozygous lines most of the transgenic lines which inherited the bar gene became sensitive to the herbicide BASTA ${ }^{\circledR}$ in subsequent generations (Fig. 5). This result is similar to those observed by Richter et al. ${ }^{33}$ In this study, 
polygalacturonase inhibiting proteins (PGIP) from raspberry and stilbene synthase $\left(V_{s} t\right)$ from grape were expressed in pea. The PGIP, as well as the bar gene, exhibited independent expression dynamics in different generations. They observed the silencing of the bar gene in the T1 of some lines.

In some cases, this may be due to gene inactivation or silencing, methylation, co-suppression or due to the physical loss of the gene due to incomplete T-DNA transfer to the plant genome, since the bar gene is located next to the chitinase and glucanase genes near the left border of T-DNA. ${ }^{34,35}$

Crude extracts of different transgenic $\mathrm{F}_{2}$ and $\mathrm{F}_{3}$ progenies showed inhibitory effects on spore germination of Trichoderma harzianum in contrast to extracts from isogenic transgenic lines, untransformed pea line (negative control) or $\mathrm{Na}$-acetate buffer as shown in Figure 5. ${ }^{36}$

\section{Materials and Methods}

Plant material. Parental transgenic pea lines (03-041,3,6,1-F and 02-04-7-1,1,2,3,2-F) were carrying a Chit 30 gene coding for chitinase from Streptomyces olivaceoviridis, ${ }^{34}$ as well as (98-49-6,1-1-5-9-3-) containing gluc gene coding for $1,3-\beta$-glucanase from barley (Hordeum vulgare) ${ }^{35}$ in their homozygous state. The chitinase and glucanase genes were inserted in the T-DNA region of the pGreenII binary vector under the control of double 35S-promoter (from cauliflower mosaic virus) and a pA-terminator (Fig. 6). A selectable marker, herbicide resistant bar gene from Streptomyces hygroscopicus was inserted between the NOS-promoter and a $\operatorname{Tg} 7 \mathrm{pA}$-terminator.

Cross pollination. Transgenic seeds were grown at $17-22^{\circ} \mathrm{C}$ in a $16 / 8 \mathrm{~h}$ day night interval. At flowering stage, after 6-8 weeks of planting, mature pollen was transferred manually from the donor plants to the stigma of emasculated recipient flower for pollination, the flowers were closed, labelled and let to continue growing until setting the seeds. Mature crossed seeds were harvested and dried before germination in greenhouse for multiplication and further analyses. Detection of integrated genes into transgenic pea plants was done by polymerase chain reaction (PCR).

Detection of transgenic progenies by PCR. Genomic DNA was isolated from transgenic and non-transgenic plants using the CTAB (cetyl-trimethyl ammonium bromide) extraction method after Doyle and Doyle. ${ }^{37}$ Specific primers were used to detect glucanase gene (forward: 5'-TGC ATG GCG TGT GCT ACG GA-3'/reverse: 5'-TTT CCA CCG ATG CCC CGA AC-3'), chitinase gene (forward: 5'-GGT GAC ATC GTC CGC TAC AC-3'/ reverse: 5'-CTA GAT CAG CAG TAG AGG TT-3') and HMG (high-mobility group protein, accession X99373) gene as an

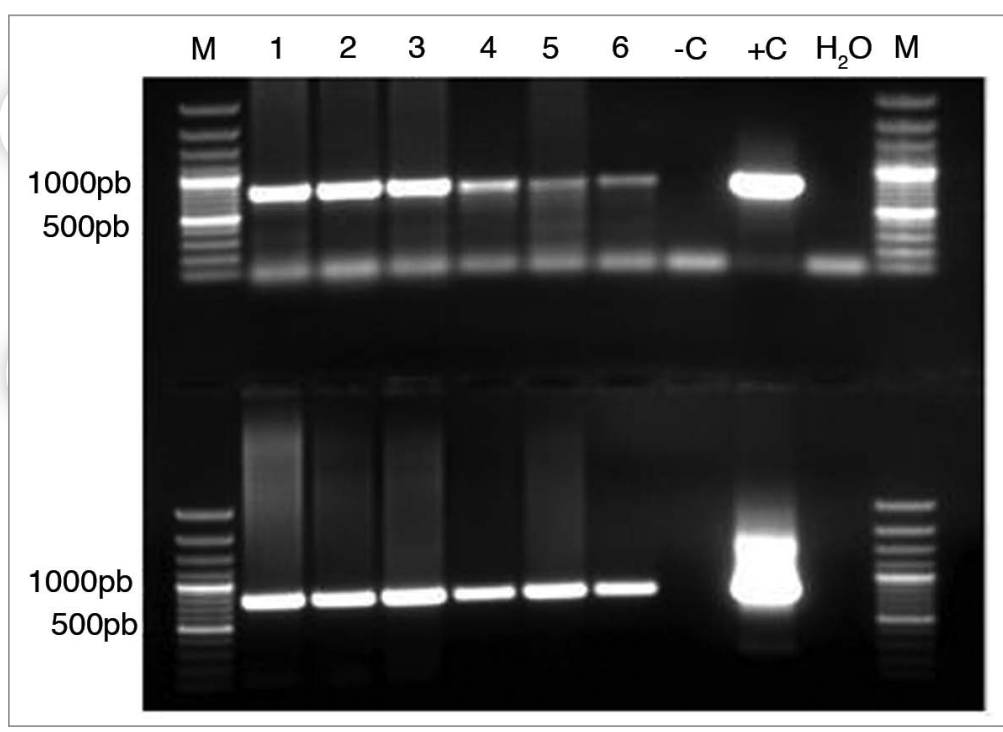

Figure 3. $\mathrm{RT}$-PCR results of $\mathrm{F}_{4}$ crossed transgenic plants using chit primer (upper photo) and gluc primers (lower photo). Lanes 1-6 (07/18-1-2-3-3, 07/18-1-2-2-3, 07/20-2-2-2-2, 07/20-2-2-2-4, 07/38-1-2-3-1, 07/38-1-2-3-3), +C: positive controls: plasmid pGII-chit 30 \& pGII-gluc; -C: negative control untransformed plant; M: 100 bp DNA molecular marker.

internal control (forward: 5'-ATG GCA ACA AGA GAG GTT AA-3'/reverse: 5'-TGG TGC ATT AGG ATC CTT AG-3').

PCR was carried out in a volume of $25 \mu \mathrm{l}$ reactions consisting of $1 \mu \mathrm{l}$ template DNA (30-50 ng), $5 \mu \mathrm{l} 5 \mathrm{x}$ Green GoTaq ${ }^{\circledR}$

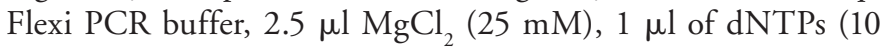
$\mathrm{mM}), 1 \mu \mathrm{l}(10 \mathrm{pmol})$ each primer, $0.2 \mu \mathrm{l}(1 \mathrm{U}) \mathrm{GoTaq}^{\circledR}$ polymerase (Promega) and $13.3 \mu \mathrm{l}$ sterile nuclease-free water. The amplification was carried out in a T3 thermal cycler (Biometra). Positive, negative and water controls were also run along with DNA samples of interest to avoid the detection of false positive or false negative results.

PCR conditions were: initial denaturing at $94^{\circ} \mathrm{C}$ for $1 \mathrm{~min}$, 30 cycles at [denaturing at $94^{\circ} \mathrm{C}, 45 \mathrm{~s}$; annealing at $60^{\circ} \mathrm{C}$, 


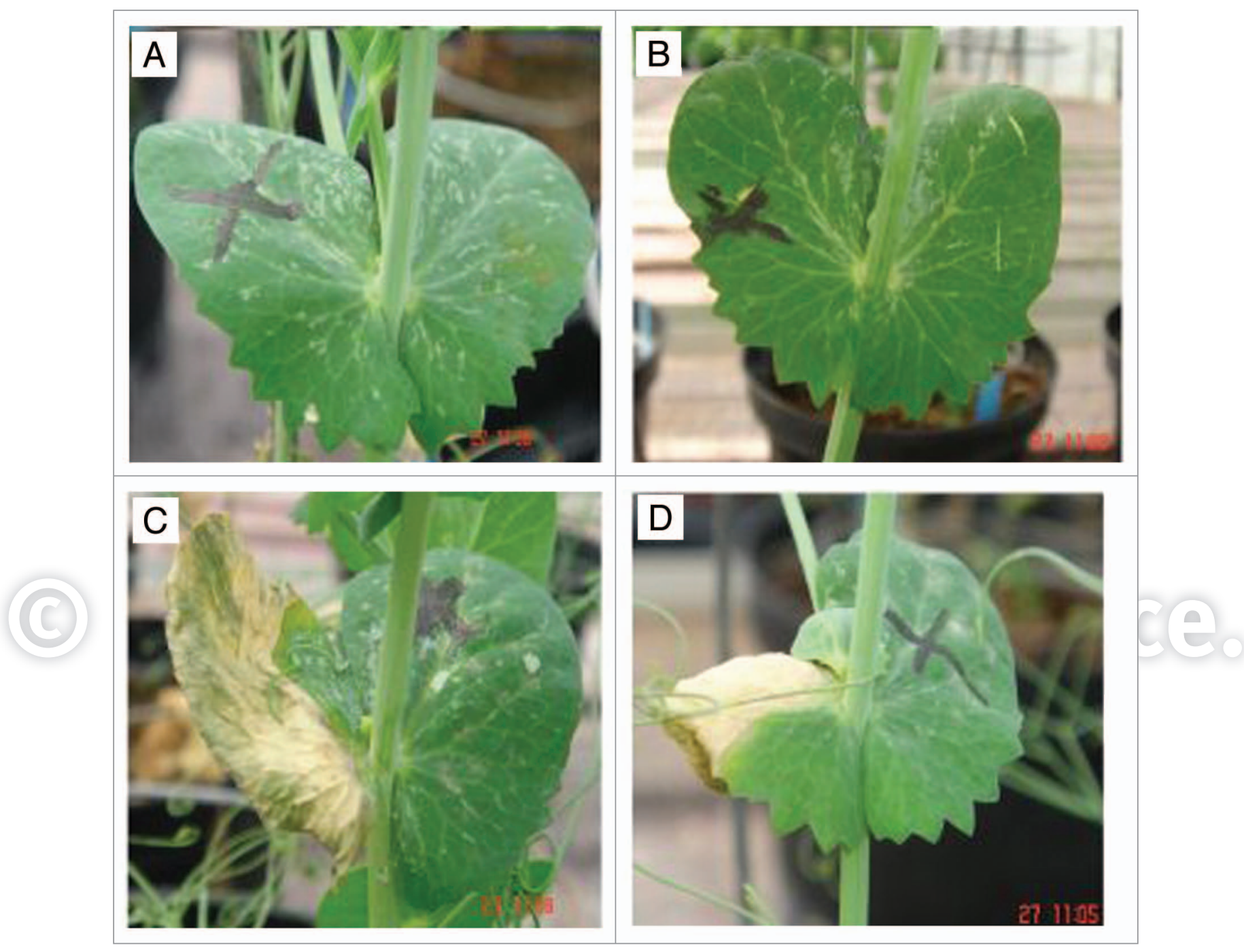

Figure 4. Leaf paint assay after one week of $600 \mathrm{mg} / \mathrm{l} \mathrm{BASTA}$ application: (A) crossed transgenic plant; (B) transgenic chitinase plant; (C) trangenic glucanase plant; (D) untransformed control. The unmarked leaflet present the treated leaflet with herbicide while the marked one is control without treatment.

$45 \mathrm{~s}$; extension at $72^{\circ} \mathrm{C} ; 45 \mathrm{~s}$; final extension at $72^{\circ} \mathrm{C}, 5 \mathrm{~min}$. The PCR products ( $20 \mu \mathrm{l}$ of sample per lane) along with $100 \mathrm{bp}$ DNA molecular weight marker were electrophoresed on $1.0 \%$ agarose gel stained with $\mathrm{EtBr}$ and visualized by UV transillumination.

Southern blot analysis. To analyse the integration pattern and copy number of introduced genes, Southern blot was performed. About $30 \mu \mathrm{g}$ of genomic DNA was digested with a restriction enzyme (BamHI), separated by electrophoresis ( $0.8 \%$ agarose), depurinated, denaturated and blotted onto a positively charged nylon membrane (Roche Diagnostics $\mathrm{GmbH}$ ). Non-radioactive detection method using digoxigenin (DIG) system according to the application manual for filter hybridization (Roche Diagnostics $\mathrm{GmbH}, 2000$ ) was applied. Filters were prehybridized with DIG Easy Hyb for $3 \mathrm{~h}$ at $42^{\circ} \mathrm{C}$ then hybridized with PCR-DIG-labelled probes over night at $42^{\circ} \mathrm{C}$, the probe was prepared according to the manufacturer's manual (Roche Diagnostics GmbH, Mannheim, Germany) briefly to $50 \mu \mathrm{l}$ final volume the following compounds were added $1 \mu \mathrm{l}$ template
DNA (30-50 ng), $10 \mu \mathrm{l}$ 5x Green GoTaq ${ }^{\circledR}$ Flexi PCR buffer, $5 \mu \mathrm{l} \mathrm{MgCl}(25 \mathrm{mM}), 0.25 \mu \mathrm{l}$ of dNTPs $(10 \mathrm{mM}), 1 \mu \mathrm{l}$ (10 pmol) each primer, $2 \mu \mathrm{l}$ PCR Dig labeling mix (Roche) $1 \mu \mathrm{l}$ (1 U) GoTaq ${ }^{\circledast}$ polymerase. The quality of the probe was checked on $1 \%$ agarose gel and compared with control probe without adding PCR Dig labeling mix.

Expression analysis via RT PCR. Total RNA was isolated from very young pea leaves using Trizol reagent (RNAtidy G, AppliChem) according to the manufacturer's protocol and quantified by spectrophotometer, RNA integrity was checked by denatured agarose gel electrophoresis in MOPs buffer. Five micrograms of total RNA was used for cDNA synthesis and RT-PCR according to the manufacturer's manual (MBI Fermentas). cDNA was used as template for the normal PCR as mentioned earlier.

Leaf paint assays. Leaf paint assay was done to verify the expression of the bar gene. The bar gene activity in crossed transgenic plants was assayed according to Schroeder et al..$^{38}$ The upper surface of a leaflet was thoroughly wetted by painting with an 


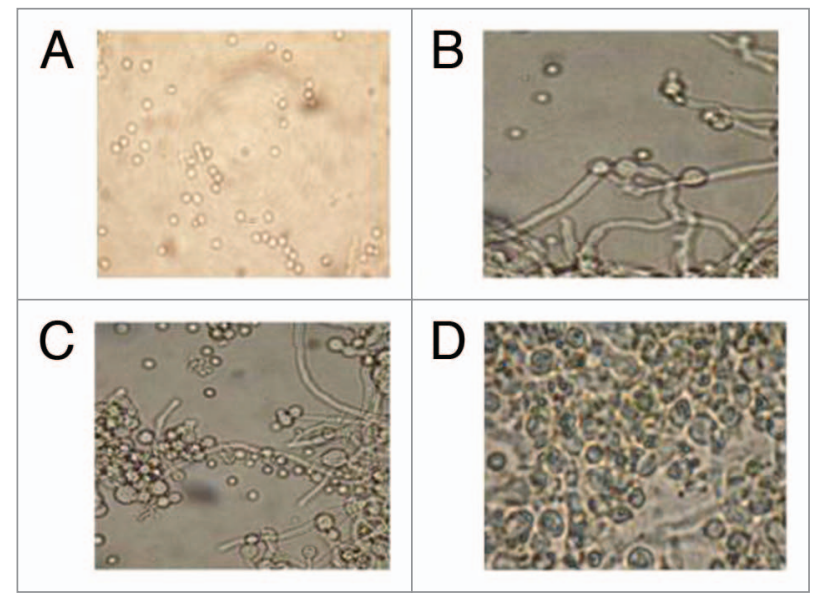

Figure 5. The effect of recombinant protein on the spore germination of Trichoderma harzianum under light microscope (x40) (1) Spore suspension on the first day. (2) Spore suspension with untransformed pea crude extract on the second day. (3) Spore germination in protein extract from isogenic parental transgenic pea (Chitinase line 02-04-7-

$1,1,2$ ) on the second day. (4) Spore germination in protein extract from $F_{2}$ crossed transgenic pea on the second day.

aqueous solution of herbicide Basta ${ }^{\circledR}$ (Aventis GmbH, Frankfurt, Germany) with a final Phosphinothricin (PPT) concentration of $600 \mathrm{mgl}^{-1}$ and $0.1 \%$ Tween 20 . The opposite leaflet of each pair was left untreated as a control, the herbicide effect was evaluated 1 week later.

In vitro bioassay. In vitro bioassays were performed for testing the synergistic effect of the $\mathrm{F}_{2}$ and $\mathrm{F}_{3}$ crossed transgenic plants to inhibit fungal spore germination using Trichoderma harzianum (T12 strain), ${ }^{39} 40 \mu \mathrm{l}$ spore suspension of T. harzianum was mixed with $40 \mu \mathrm{l}$ protein crude extract and incubated overnight at ambient RT. The effect of crude extracts on spore germination was examined under a light microscope.
Table 1. Leaf paint summary

\begin{tabular}{|c|c|c|c|c|}
\hline Generation & Plant type & Total & $(+)$ & $(-)$ \\
\hline \multirow[t]{5}{*}{$\mathrm{F}_{1}$} & pyramided progeny & 76 & 63 & 13 \\
\hline & Chitinase & 14 & 14 & 0 \\
\hline & Glucanase & 9 & 0 & 9 \\
\hline & Untransformed & 4 & 0 & 4 \\
\hline & & 103 & & \\
\hline \multirow[t]{5}{*}{$F_{2}$} & Pyramided progeny & 147 & 117 & 30 \\
\hline & Chitinase & 21 & 21 & 0 \\
\hline & Glucanase & 24 & 19 & 5 \\
\hline & Untransformed & 28 & 0 & 28 \\
\hline & & 220 & & \\
\hline \multirow[t]{5}{*}{$\mathrm{F}_{3}$} & Pyramided progeny & 70 & 59 & 11 \\
\hline & Chitinase & 15 & 15 & 0 \\
\hline & Glucanase & 13 & 5 & 8 \\
\hline & Untransformed & 5 & 0 & 5 \\
\hline & & 103 & & \\
\hline \multirow[t]{5}{*}{$\mathrm{F}_{4}$} & Pyramided progeny & 60 & 51 & 9 \\
\hline & Chitinase & 12 & 12 & 0 \\
\hline & Glucanase & 12 & 6 & 6 \\
\hline & Untransformed & 4 & 0 & 4 \\
\hline & & 88 & & \\
\hline
\end{tabular}

\section{Conclusion and Outlook}

A successful combination of chitinase and glucanase transgenes in one pea line via conventional crossing was achieved in the present study. However, variation in expression and activity was observed with some lines having a higher activity than the parental transgenic lines. This may possibly be due to the hemizygous state of some of the crossed transgenic lines or due to the

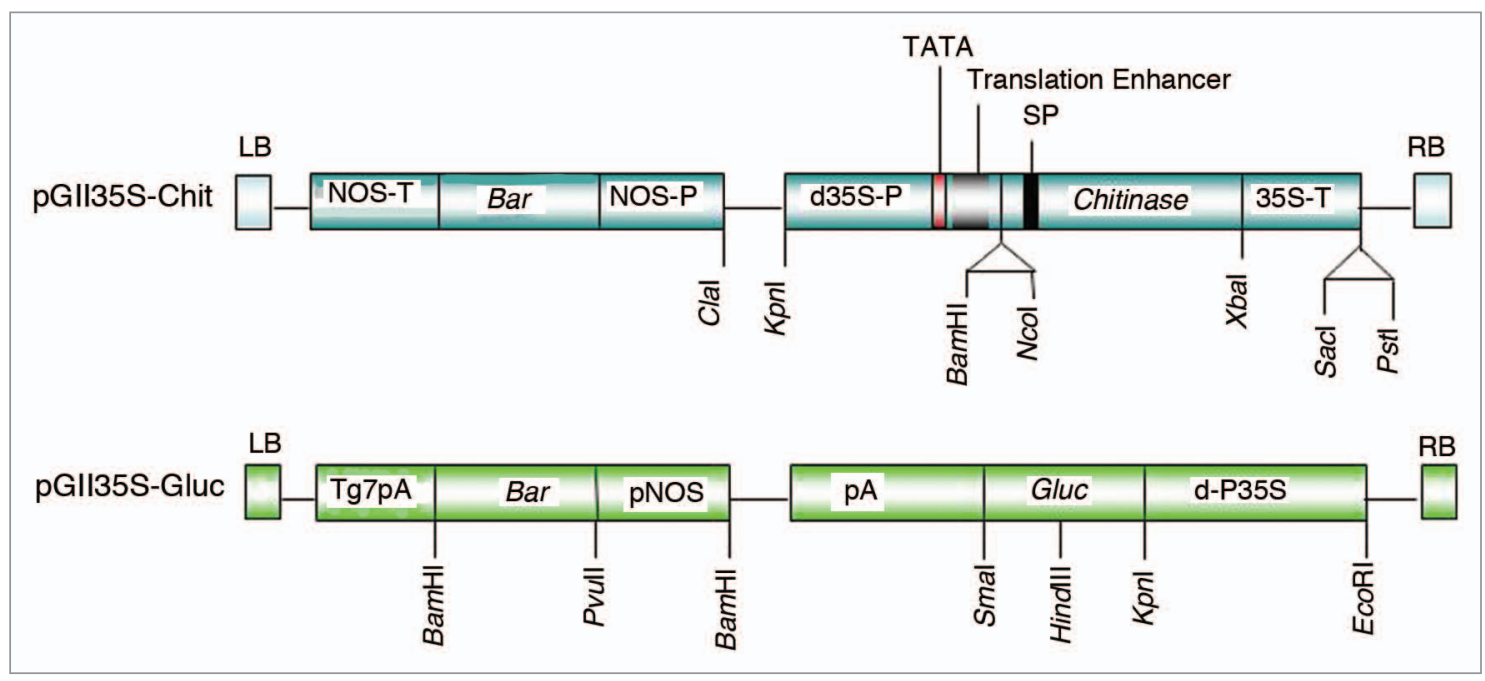

Figure 6. Physical maps of the binary vectors used for pea transformation pGreen II with double 35S promoter (P35S). (d-P35s: double 35S promoter SP: Arabidopsis signal peptide, T: terminator, P: promoter, NOS: Agrobacterium nopaline synthase gene, Bar: herbicide resistance selectable marker from Streptomyces hygroscopicus, RB: right border, LB: left border). 
constitutive expression of the $35 \mathrm{~S}$ promoter. It would be interesting to test the antifungal effects in vivo under field conditions with different fungi. Furthermore, these lines may be used in subsequent studies for stacking of more genes and to understand the inheritance of transgenes since it is different from traditional Mendelian genetics.

\section{References}

1. Ali SM, Sharma B, Ambrose MJ. Current status and future strategy in breeding pea to improve resistance to biotic and abiotic stresses. Euphytica 1994; 73:115-26.

2. Benítez T, Rincón AM, Limón MC, Codón AC Biological mechanisms of Trichoderma strains. Int Microbiol 2004; 7:249-60.

3. Lawyer AS. Diseases caused by Ascochyta. In: Compendium of Pea Diseases Hagedorn DJ, ed. American Phytopathological Society, St. Paul MN 1984:11-3.

4. Xue AG, Warkentin TD, Greeniaus MT, Zimmer RC. Genotypic variability in seedborne infection of field pea by Mycosphaerella pinodes and its relation to foliar disease severity. Can J Plant Pathol 1996; 18:370-4.

5. Ryals JA, Neuenschwander UH, Willits MG, Molina A, Steiner HY, Hunt MD. Systemic acquired resistance. Plant Cell 1996; 8:1809-19.

6. Van Loon LC. Induced resistance in plants and role of pathogenesis-related proteins. Eur J Plant Pathol 1997; 103:235-70.

7. Dana M, José A, Pintor-Toro JA, Cubero B. Transgenic tobacco plants overexpressing chitinases of fungal origin show enhanced resistance to biotic and abiotic stress agents. Plant Physiol 2006; 142:722-30.

8. Jach G, Gornhardt B, Mundy J, Logemann J, Pinsdorf $\mathrm{E}$, Leah R, et al. Enhanced quantitative resistance against fungal disease by combinatorial expression of different barley antifungal proteins in transgenic tobacco. Plant J 1995; 8:97-109.

9. Lorito M, Woo SL, Fernandez IG, Colucci G, Harman GE, Pinto-Toro JA, et al. Genes from mycoparasitic fungi as a source for improving plant resistance to fungal pathogens. Proc Natl Acad Sci 1998; 95:7860-5.

10. Hong JK, Hwang BK. Promoter activation of pepper class II basic chitinase gene, CAChi2 and enhanced bacterial disease resistance and osmotic stress tolerance in the CAChi2-overexpressing Arabidopsis. Planta 2006; 223:433-48.

11. Broglie K, Chet I, Hollidays M, Cressman R, Biddle P, Knowlton S, et al. Transgenic plants with enhanced resistance to fungal pathogen Rhizoctonia solani. Science 1991; 254:1194-7.

12. Lin W, Anuratha CS, Datta K, Potrykus I, Muthukrishnan S, Datta SK. Genetic engineering of rice for resistance to sheath blight. Nat Biotechnol 1995; 13:686-91.

13. Nishizawa Y, Nishio Z, Nakazono K, Soma M, Nakajima E, Ugaki M, et al. Enhanced resistance to blast (Magnaporthe grisea) in transgenic rice by constitutive expression of rice chitinase. Theor Appl Genet 1999; 99:383-90.
14. Cornelissen BJC, Melchers LS. Strategies for control of fungal disease with transgenic plants. Plant Physiol 2000; 101:709-12.

15. Leah R, Tommerup H, Svendsen I, Mundy J. Biochemical and molecular characterization of three barley seed proteins with antifungal properties. J Biol Chem 1991; 266:1464-573.

16. Melchers LS, Stuiver MH. Novel genes for disease-resistance breeding. Curr Opin Plant Biol 2000; 3:147-52.

17. Zhu Q, Maher EA, Masoud S, Dixon RA, Lamb CJ. Enhance protection against fungal attack by constitutive co-expression of chitinase and glucanase genes in transgenic tobacco. Nat Biotechnol 1994; 12:807-12.

18. Mauch F, Mauch-Mani B, Boller T. Antifungal hydrolases in pea tissue II. Inhibition of fungal growth by combinations of chitinase and $\beta$-1,3-glucanase. Plant Physiol 1988; 88:936-42.

19. Chye ML, Zhao KJ, He ZM, Ramalingam S, Fung $\mathrm{KL}$. An agglutinating chitinase with two chitin-binding domains confers fungal protection in transgenic potato. Planta 2005; 220:717-30.

20. Jongedijk E, Tigelaar H, Van Roekel JSC, BresVloemans SA, Dekker I, Van den Elzen PJM, et al. Synergistic activity of chitinases and $\beta$-1,3-glucanases enhances fungal resistance in transgenic tomato plants. Euphytica 1995; 85:173-80.

21. Dafny-Yelin M, Tzfira T. Delivery of multiple transgenes to plant cells. Plant Physiol 2007; 145:1118-28.

22. Francois IEJA, Broekaert WF, Cammue BPA. Different approaches for multi-transgene-stacking in plants. Plant Science 2002; 163:281-95.

23. Halpin C, Boerjan W. Stacking transgenes in forest trees. Trends Plant Sci 2003; 8:363-5.

24. Ali Z, Schumacher HM, Heine-Dobbernack E, El-Banna A, Hafeez FY, Jacobsen HJ, et al. Dicistronic binary vector system-A versatile tool for gene expression studies in cell cultures and plants. J Biotechnol 2010; 145:9-16

25. Cao J, Zhao JZ, Tang JD, Shelton AM, Earle ED Broccoli plants with pyramided crylAc and crylC Bt genes control diamondback moths resistant to Cry1A and Cry1C proteins. Theor Appl Genet 2002; 105:258-64.

26. Zhao JZ, Cao J, Li YX, Collins HL, Roush RT, Earle $\mathrm{ED}$, et al. Transgenic plants expressing two Bacillus thuringiensis toxins delay insect resistance evolution. Nat Biotechnol 2003; 21:1493-7.

27. Datta K, Baisakh N, Thet KM, Tu J, Datta SK. Pyramiding transgenes for multiple resistance in rice against bacterial blight, yellow stem borer and sheath blight. Theor Appl Genet 2002; 106:1-8.
28. Matzke MA, Matzke AJM. Epigenetic silencing of plant transgenes as a consequence of diverse cellular defence responses. Cell Mol Life Sci 1998; 54:94-103.

29. Jones JDG, Dunsmuir P, Bedbrook J. High level expression of introduced chimeric genes in regenerated transformed plants. EMBO J 1985; 6:3901-7.

30. Boller T. Chemoperception of microbial signals in plant cells. Annu Rev Plant Physiol Plant Mol Biol 1995; 46:189-214.

31. Nadolska-Orczyk A, Orczyk W. Study of the factor influencing Agrobacterium-mediated transformation of pea (Pisum sativum L.). Mol Breeding 2000; 6:185-94

32. Hanafy M, Pickardt Th, Kiesecker H, Jacobsen HJ. Agrobacterium-mediated transformation of faba bean (Vicia faba L.) using embryo axes. Euphytica 2005; 142:227-36.

33. Richter A, de Kathen A, de Lorenzo G, Briviba K, Hain $\mathrm{R}$, Ramsay G, et al. Transgenic peas (Pisum sativum $\mathrm{L}$.) expressing polygalacturonase inhibiting protein from raspberry (Rubus idaeus) and stilbene synthase from grape (Vitis vinifera). Plant Cell Rep 2006; 25:1166-73.

34. Hassan F, Meens J, Jacobsen HJ, Kiesecker H. A family 19 chitinase (Chit 30) from Streptomyces olivaceoviridis ATCC 11,238 expressed in transgenic pea affects the development of $T$. harzianum in vitro. J Biotechnol 2009; 143:302-8; http://dx.doi.org/10.1016/j.jbiotec.2009.08.011.

35. Richter A. Züchtung mit transgenen pflanzen: Kombination rekombinanter pilzresistenzgene mittels Kreuzung transgener erbsenlinien (Pisum sativum L.) Ph.D., Thesis. University of Hannover 2005; 154

36. Selatsa AA, Papenbrock J, Hassan F, Jacobsen HJ Combination of antifungal genes (chitinase and glucanase) to increase the resistance level of transgenic pea (Pisum sativum L.) against fungal diseases. In: Competition for resources in a changing world-New drive for rural development. Proceeding of Tropentag. October 7-9, 2008. University of Hohenheim, Stuttgart.

37. Doyle JJ, Doyle JL. Isolation of plant DNA from fresh tissue. Focus 1990; 12:13-5.

38. Schroeder HE, Schotz AH, Wardley-Richardson T, Spencer D, Higgins TJV. Transformation and regeneration of two cultivars of pea (Pisum sativum L.). Plant Physiol 1993; 101:751-7.

39. Schlumbaum AF, Mauch F, Vögeli U, Boller T. Plant chitinases are potent inhibitors of fungal growth. Nature 1986; 324:365-7. 